\title{
Supplying 2C (Critical and Creative Thinking) Basic Concept as an Effort to Build the Ventures of Vocational School Students in Product Design
}

\author{
Asep Sufyan Muhakik Atamtajani ${ }^{1 *}$, Sheila Andita Putri ${ }^{1}$ \\ ${ }^{1}$ Department of Product Design, School of Creative Industries, Telkom University, Bandung, Indonesia \\ ${ }^{*}$ Corresponding author. Email: krackers@telkomuniversity.ac.id
}

\begin{abstract}
Vocational education is part of the education system that prepares a person to be more able to work in one occupational group or one occupation than other fields of work. Vocational High School (SMK) is one of the educational unit level institutions that has the role of creating quality and competent Human Resources (HR) in their fields. Quality Human Resources (HR) are ready-to-use workers, i.e. workers who demonstrate high mastery of science, technology, and skills followed by good morals, ethics, and self-character. The Creative thinking component consists of; Identify and challenge assumptions, recognize the importance of context, imagine and explore alternatives, develop reflective scepticism. Creative thinking always considers rejecting standard patterns in problem solving.
\end{abstract}

Keywords: Critical and Creative Thinking, ventures, vocational school students, product design

\section{INTRODUCTION}

Vocational High School (SMK) is one of the educational unit level institutions that has the role of creating quality and competent Human Resources (HR) in their fields. Quality Human Resources (HR) are ready-to-use workers, i.e. workers who demonstrate high mastery of science, technology, and skills followed by good morals, ethics, and self-character. If these qualities are owned by every SMK graduate, surely Indonesia will not lack a potential future generation. This is a reflection of the next generation of the ideal nation.

According to Evans and Edwin [1], vocational education is part of the education system that prepares a person to be capable to work in specific work field. According to the explanation of Law Number 20 Year 2003 Article 15, vocational education is secondary education that prepares students, especially to work in certain fields. Vocational education consists of Vocational High Schools, and Aliyah Vocational Madrasah.

SMK Garuda Nusantara (Garuda Nusantara IT Vocational School) is a private school in the city of Cimahi. Located in Jl. Sangkuriang No. 30, Garuda Nusantara Vocational School Cimahi is an IT-based school that has 6 majors. Those 6 majors are Computer Network Engineering (CNE), Software Engineering (SE), Multimedia (MM), Animation (AN), Access Network Engineering (ANE), and Office Administration (OA).

Currently Garuda Nusantara Vocational School has done a lot of partnership, both national and international. One of their partnership is with academics in Norway for student exchange, training and so on. Garuda Nusantara Vocational School graduates are highly responded in the workforce. The school graduates placed in several industries in the Cimahi area. Since its establishment in 2009 the number of students has reached more than 2000 students with a ratio of the number of teachers to 150 people.

The common problem that occurs nationally at this time is the highly competitive employment. It means that the preparation of students to be adaptive and strategical in the workplaces or entrepreneurship are essentials. The preparation of the students can be delivered through creative thinking. Creative thinking is an activity in questioning the assumptions that underlie our habits, habits of way of thinking, ways of acting, and then is ready to think and act differently on the basis of critical questions.

The Creative thinking component consists of; Identify and challenge assumptions, recognize the importance of context, imagine and explore alternatives, develop reflective scepticism. Creative thinking always considers rejecting standard patterns in problem solving. Those who think creatively have interests in a variety of related and divergent fields, take several perspectives on a problem, use trial-and-error methods in their experiments, and have a future orientation with a sense of self- confidence.

It is expected that this research can provide students with understanding in determining attitudes and critical thinking in facing future challenges and industry needs in terms of design solutions. The target of the results of this research is to aid the students to produce variant ideas and valuable design solutions. Implementation of the results of this training can foster motivation can be directly operated in the field and has good quality and can last a long time. Designed products can provide inspiration to develop designs in the future.

\section{METHOD}

The target of the results of this service is to train the Garuda Nusantara Vocational School students to be creative, proposing different ideas, and try to implement their ideas 
to a certain issue with Design Thinking approach. This Design Thinking Method is a different approach than the usual Teaching Method that the students get at school. Implementation of the results of this design training is to turn ideas into something applicable with good quality design that can last a long time. The development of this new design is a combination of the development concept to visualizing ideas, with digital modelling workshops for the students.

To deliver the Design Thinking into the basic designing process, the method will be divided into two phases, socialization and application. The first phase is the basic foundation of the whole process to raise the action consciousness. In this phase, the research facilitator will give them the basic theory of product designing with some examples. This phase also consists of the basic explanation of the design thinking and what the students should proceed in the next step.

The second phase is application. In this phase, the basic theory from the previous phase are put to use. This phase includes brainstorming and visualization process. The students are expected to explore new ideas to find design alternative. The design solutions will be visualized in prototype and 3D rendering picture. The definition of visual is what is captured by the sense of sight [2]. Factors that influence in terms of visuals are as follows:

a. The number of visual elements contained in the object.

b. Arrangement of visual elements that exist on the object.

c. The material used includes the characteristics of the treatment and aesthetic characteristics contained in the material.

d. Characteristics of individuals who carry out processing. These characteristics will influence how a form problem is solved

During the visualization process, the student might need assistance to achieve the harmony in their ideas and visualization. Harmony can be defined as the determination of visual order or the relationship of visual quality between visual elements in a composition. Assessment of harmony depends on sensitivity and senses [3]. The end result will be collected to evaluate the whole process. The diagram below will show the whole process.

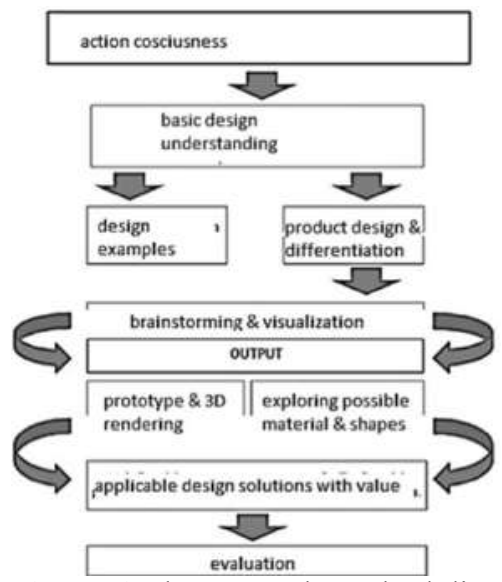

Figure 1 The research method diagram

\section{RESULT AND DISCUSSION}

The Design thinking process involves brainstorming process and visualizing the ideas to be presented as the new design solutions. In this process, students are encouraged to be active to find solutions. This is the opposite of the passive approach they usually get in school, where they only do the assignment, they asked to do without providing their own solutions.

To deliver this design thinking method, the approach divided into two phases, Socialization and Application through workshops.

\subsection{The first phase: socialization}

The key in narrowing the gap between the theoretical approaches in practice is to make sure the step- by- step process is explained in detail and clear [4]. This is exactly why the first phase of the activity began with the socialization of Design Thinking Method. This first phase held in Garuda Nusantara Vocational School Cimahi and delivered by the facilitator/ lecturer member Mr. Edwin Buyung Syarif, M.Sn. as the speaker. There are many topics raised from the creation of intellectual property works and problem solving in the community such as waste management in housing. Waste itself can be defined as a substance or waste material produced from a production process, both industrial and domestic (household) [5]. As the space over-loaded with students and the high enthusiasm, the research team initiated to invite them to the TelkomUniversity.

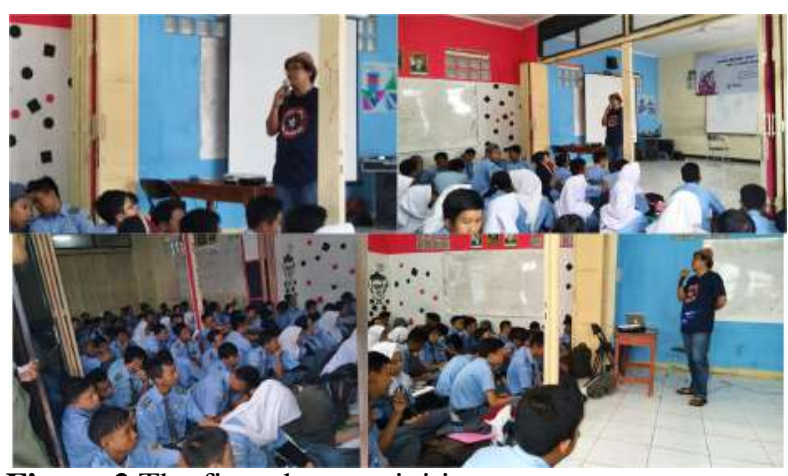

Figure 2 The first phase activities

\subsection{The second phase: application}

The second phase is the application of the Design Theory. The application delivered by the workshop, supervised by the team of Product Design lecturers as Facilitators. The whole Workshop activities involved Lecturers, Associations, and Students of Garuda Nusantara Vocational School.

In this phase, Students are invited to brainstorm out ideas and input. The task of the lecturer as a mentor\& facilitator is to oversee the activities of students in producing a design solution. The students sorted out the idea from the brainstorming process to find the possible 
design solution. According to Atamtajani [6], each idea can have unique characteristics. These characteristics can arise depending on the personality of the maker. This is what differentiates works from one another depends on the target user. The design process also can be used as a documentation in preserving tradition and at the same time be regarded as a reference for developing it further, as shown in Atamtajani [7].

To make the process successfully delivered, the Students are divided in several groups and motivated to be able to play an active role in these activities. This step is applied to make sure the whole program between Telkom University and Garuda Nusantara Vocational School can be executed properly and bring benefits to the students. According to Lantu, Pulungan, and Yudiarti [8], an effective program generates results that comply with the planning and objectives of the program. Further, an effective program is one that meets the needs of the community (in this case, students) itself. Design thinking works better while in group, as in Yudiarti and Lantu [9], team members are supporting and facilitating each other while delegating the task and roles to the member that suitable to each member skills with also have equal responsibilities.

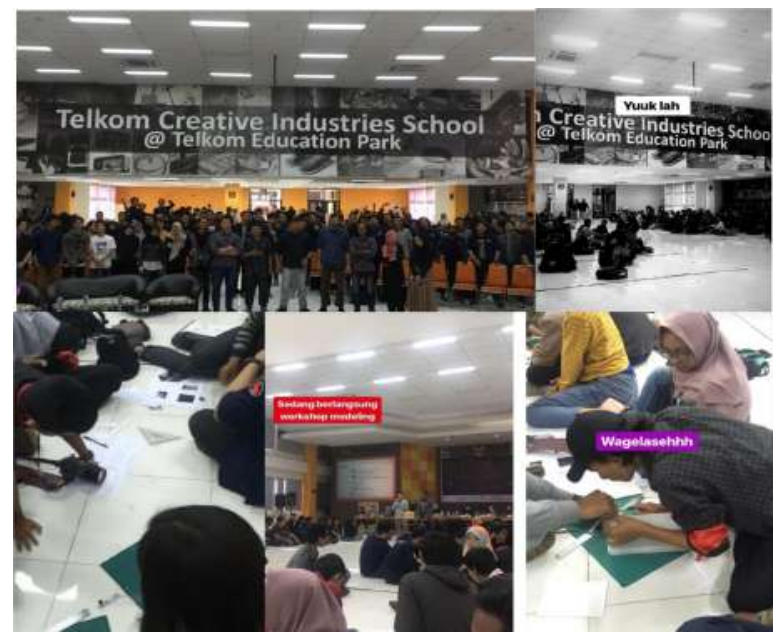

Figure 3 The second phase activities

This phase itself must be carried out for one full day. During this phase, all of the Students participants are involved and provide input expected by students in finding design solutions. They are encouraged to visualize the design solution with the manual tools and digital software, which they are already familiar with. They made 3 Dimensional Models from paper and then presenting their project with the Digital Drawing made with software. However, since the capability each individual in teams did not equal, whether in skill and experience [10], this might affect the end result of each teams.

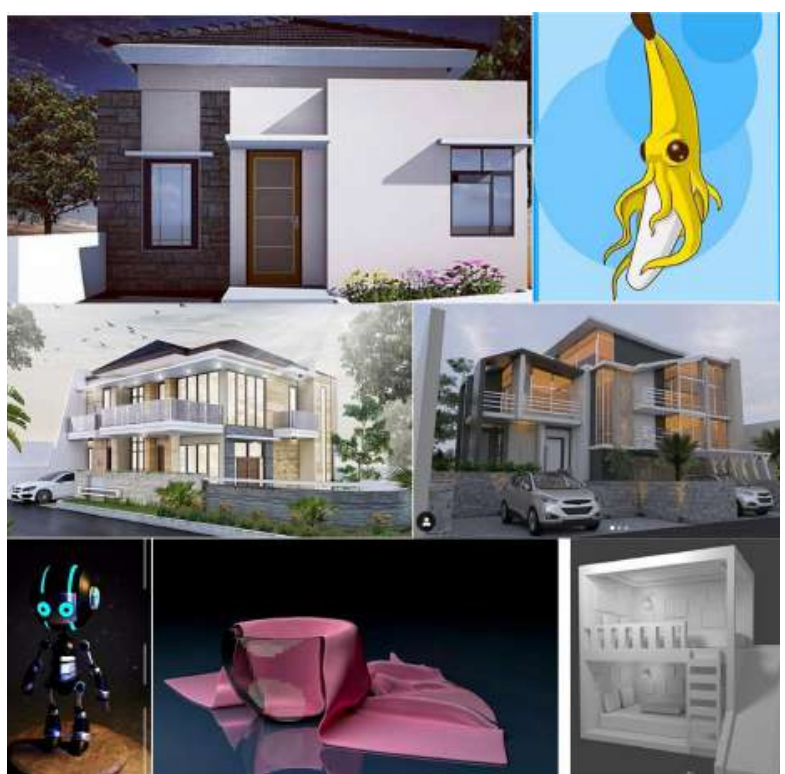

Figure 4 The students end results

As seen in the end result of the whole process, The Students can produce design concept based on the issue they analysed and discussed. This is the difference between the approach in their school and in the workshops (training), where the students are motivated to find their own solution and executed the plan instead of just receiving certain orders. When they are doing the brainstorming and get their own solutions, the result of the assignment become more variable. The active process creates more enjoyable learning process with good results. The results of the workshop activities are evaluated through assignments given by the teacher at the Vocational School later.

\section{CONCLUSIONS}

The results of several activities starting from socialization to being involved in public lecture activities in the faculties of the creative industry are very useful and help students to be creative. The students learned the application of Design Thinking process to produces a solution by design. They also capable to visualized the new idea, both manually and digitally, and present it as a valuable design solution to an assignment. The design thinking approach helps them to come up with different solution and actively involved in using their skills to finish certain assignments. This is the difference between the passive approaches where the students usually get in school.

\section{REFERENCES}

[1] Evans, Rupert N, dan Edwin, Lewis H. 1978. "Foundation of Vocational Education". Columbus. Ohio: Charles E. Merril Publishing Company. 
[7] Atamtajani, Asep Sufyan Muhakik. (2018) "Filigree Jewelry Product Differentiation (Case Study Filigree Kota Gede Yogyakarta)." Bandung Creative Movement (BCM) Journal 4.2

[3] Wallschelaeger, C. (1992). "Basic Virtual Concepts and Principle" Wm.C Brown Publisher.

[4] Putri, Sheila Andita. (2018). "Application of Branding Canvas Method in Mechanical Modified Hoe". Proceedings of the 5th Bandung Creative Movement International Conference on Creative Industries 2018

[5] Justin, Joshua, Fajar Sadika, and Asep Sufyan. (2015). "Eksplorasi Limbah Kaca Studi Kasus Industri Mebel." eProceedings of Art \& Design 2.2

[6] Atamtajani, Asep Sufyan Muhakik. 2014. Gaya Perhiasan Trapart Karya Nunun Tjondro (Analisis Personalisasi dan Diferensiasi terhadap Ragam Aksesori). Bandung: ISBI Bandung.
[8] Lantu, D.C., Pulungan, S.A., Yudiarti, D. (2017). "Analyzing The Effectiveness of a Joint Corporate Social Responsibility Program to Empower People in an Indonesian Village". International Journal of Business and Society, 18(S2), 323-338.

[9] Yudiarti, D., Lantu, D.C. (2015). “Organizing Creative People in Creative Industry: Preliminary Study About Implementation of Design Thinking in Indonesia". Proceedings of 5th Business, Economics and Communications International Conference. Phitsanulok, Thailand.

[10] Yudiarti, D., Lantu, D.C. (2017). "Implementation Creative Thinking for Undergraduate Student: A Case Study of First Year Student in Business School". Advanced Science Letters, 23(8), 7254-7257. 